\title{
Environmental and socioeconomic determinants of leptospirosis incidence in Colombia
}

\author{
Determinantes ambientales y socioeconómicos \\ asociados con incidentes en casos de \\ leptospirosis en Colombia
}

\section{Determinantes ambientais e socioeconômicos associados a casos incidentes de leptospirose na Colômbia}

Juan David Gutiérrez 1

Ruth Arali Martinez-Vega 2

Hector Botello 3,4

Freddy Jesús Ruiz-Herrera 4

Laura Carolina Arenas-López 1

Karen Dayana Hernandez-Tellez 1

\begin{abstract}
Human leptospirosis is an infection that most often affects tropical countries. Since 2007, Colombia requires the notification of disease cases, enabling the observation of an increase in cases in recent years. The objectives of this article were to analyze environmental and socioeconomic variables and to evaluate their relationship with human leptospirosis cases. This is an ecological study on human leptospirosis cases aggregated by municipality and reported between 2007 and 2016. Spatial aggregation assessment was made using the Getis-Ord Gi method, and negative binomial regression was used to evaluate the relationship between environmental and socioeconomic variables with human leptospirosis. During the study period, 9,928 cases of human leptospirosis were reported, and 58.9\% of municipalities reported at least one case. Four hotspots of human leptospirosis, including 18 municipalities, were identified. The results of the negative binomial model confirmed the importance of the effects of education, poverty and some climatic variables on the decadal incidence rate of human leptospirosis. Our results confirm the importance of socioeconomic determinants such as social marginality associated with violence and education, as well as ecological variables such as rainfall, height above sea level and forest coverage on the incidence rate of human leptospirosis at municipal scale.
\end{abstract}

Leptospirosis; Environment; Socioeconomic Factors; Ecological Studies

\author{
Correspondence \\ J. D. Gutiérrez \\ Grupo Ambiental de Investigación Aplicada, Facultad de \\ Ingeniería, Universidad de Santander. \\ Calle 70 \# 55-210, Bucaramanga, Santander - 680006, \\ Colombia. \\ jdgutierrez@udes.edu.co \\ 1 Facultad de Ingeniería, Universidad de Santander, \\ Bucaramanga, Colombia. \\ 2 Escuela de Medicina, Universidad de Santander, \\ Bucaramanga, Colombia. \\ 3 Universidad Nacional, Bogotá, Colombia. \\ ${ }_{4}^{4}$ Escuela de Economía y Administración, Universidad Industrial \\ de Santander, Bucaramanga, Colombia.
}




\section{Introduction}

Leptospirosis is a disease caused by pathogenic bacteria of the Leptospira genus, affecting both humans and animals 1. Leptospirosis is one of the most common zoonoses worldwide, although it affects tropical countries most often 2 . The infection is usually transmitted to humans via water contaminated by animal urine that comes in direct contact with cutaneous lesions, the eyes or mucous membranes. Leptospirosis was a predominantly rural occupational risk until major urbanization occurred during the 20th century. Transmission risk is associated with climate, natural disasters, poverty and marginality 3 .

In Colombia, leptospirosis has been analyzed mainly from an animal health perspective, as it is prevalent in canines $4,5,6$, bovines 7,8 , pigs 9 and primates 10,11. A prevalence of over $90 \%$ in Rattus rattus, Rattus norvegicus and Mus musculus has also been documented 12,13. However, in humans, some studies have reported seroprevalences ranging from $6 \%$ to $27.7 \% 14$, and the circulation of 17 serovars has been recorded in the country 15,16

Since 2007, mandatory notification of human leptospirosis has been implemented by the Colombian National Surveillance System (SIVIGILA); subsequently, an increase in cases related to rainy and flood seasons has been observed in recent years 17 . The annual incidence of the disease in Colombia has been estimated to be 1.6 cases per 1,000,000 inhabitants 18 . However, in 2010, an incidence of 2.9 cases per 100,000 inhabitants was reported 15 . In 2012, the incidence was 2.2, with 25 confirmed deaths, for a 0.5 per $1,000,000$ inhabitants mortality and $2.4 \%$ lethality 19 .

The ecology of human leptospirosis involves a complex interaction among Leptospira, reservoir animals, humans and the environment where they coexist. Human leptospirosis is associated with overpopulation, poor sanitation and inadequate health systems in urban areas of developing countries, whereas in developed countries, where infections are currently rising in number, it is associated with outdoor recreational activities 20. However, in rural areas, transmission is associated with crop and livestock activities, and transmission risk increases during warm and rainy periods 20 . In urban areas, inadequate basic sanitation conditions enabled environments conducive to rodent-associated transmission. Other mammals, such as shrews, porcupines, domestic animals, as well as reptiles and amphibians 21, are also considered infection sources for humans.

In Rio de Janeiro, Brazil, human leptospirosis cases are associated with heavy flooding occurring 3 to 20 days before the onset of the disease 22 . The 1 to 2 months latency period between heavy rains and cases reported on the island of Réunion in the Indian Ocean is also consistent with the survival time of the pathogen in flooded areas and a 1 to 3 weeks period of human leptospirosis incubation 23 .

This study aimed to evaluate the relationships between a set of environmental and socioeconomic variables and human leptospirosis cases that occurred in Colombia from 2007 to 2016, at municipal level.

\section{Methods}

\section{Study site}

Colombia is located in the north-west region of South America between $4^{\circ}$ south latitude and $12^{\circ}$ north latitude and between $67^{\circ}$ and $79^{\circ}$ west longitude. The continental surface of the country is $1,141,748 \mathrm{~km}^{2}$. The Colombian territory presents a central mountainous system composed of three Andean mountain ranges, countryside and coastal plains and Inter-Andean valleys. Given its equatorial location Colombia's climate is tropical, i.e., hot and humid; its complex geography presents a variety of climate conditions, from warm at sea level to perpetual snow at 5,500 meters heights. Climatic conditions are influenced by the equatorial confluence zone that determines a bimodal regime across most of the territory. The wettest months are March-April and October-November, with dry seasons in January-February and July-August 24. Administratively, the country has 1,122 municipalities grouped into 33 departments.

The territory of Colombia is divided into five natural regions: Amazon, Andean, Caribbean, Orinoquia and Pacific. The Amazon and Orinoquia regions account for almost half of the Colombian 
territory but have the lowest population densities. The Amazon region is characterized by a jungle landscape, while Orinoquia has wet savannas. Most of the country's municipalities are in the Andean region (645), which is the most densely populated region in the country. Geographically, this region dominated by steep slopes and valleys of the Magdalena and Cauca rivers. The Caribbean region corresponds to the northern plains area of the country. The Pacific region is characterized by the mountains of the Western Cordillera and the valleys of rivers that flow into the Pacific Ocean.

\section{Case definition and data collection}

Human leptospirosis case information was obtained from SIVIGILA and corresponded to the period from January 2007 to December 2016 and for all municipalities in the country. The operative definition of a suspected case within the surveillance system was "a patient who has fever and headache associated with one or more of the following signs or symptoms: myalgia, conjunctival bleeding or conjunctivitis, prostration, skin rash, arthralgias, vomiting, nausea, jaundice, hepatomegaly, splenomegaly, oliguria, anuria, hemorrhages on the skin, mucous membranes and gastrointestinal tract, irritation, meningeal signs, confusion, psychosis, delirium, arrhythmias, heart failure, cough, hemoptysis, or respiratory failure" 17 (p. 6). Additional suspected cases included patients who presented signs or symptoms of a nonspecific infectious process with suggestive epidemiological antecedents 30 days before the date of the symptom onset. Such antecedents included "exposure to floods, mud or contact with stagnant water (wells, streams, lakes or rivers) possibly contaminated by work or recreational activity; or activities with occupational risk such as garbage collection, cleaning of streams, working in water or sewage systems, working with livestock and agriculture, or contact with sick animals or rodents" 17 (p. 6).

These suspected cases were confirmed by one of the following laboratory criteria: (a) positive IgM antibody by ELISA screening; (b) seroconversion in paired samples by microagglutination (MAT); (c) MAT titers greater than 1:400; (d) isolation of Leptospira spp. in blood, urine or cerebrospinal fluid culture; and (e) DNA detection by polymerase chain reaction (PCR). In addition, cases were confirmed by nexus when there was no sample by making associations between patient, time and place, or by considering an exposure to the same source of infection identified for confirmed cases. The latter was rare ( $\geq 1 \%$ of cases) 19 .

\section{Environmental variables}

The environmental variables analyzed were obtained from maps provided by the Geographic Institute Agustín Codazzi (IGAC) and the Colombian Institute of Hydrology, Meteorology and Environmental Studies (IDEAM). These maps were of soil cover, climate, height above sea level, deforested areas from 2005 to 2016, temperature, precipitation and areas susceptible to flooding. The maps were processed and analyzed using the ArcGIS 10.2 software (http://www.esri.com/software/arcgis/index.html) to obtain the set of environmental data needed for analysis. For each municipality, the proportion of land with each type of soil cover and type of climate was calculated, as was the proportion of land that was deforested between 2005 and 2016 and the proportion of land susceptible to flooding. Regarding height above sea level, mean, maximum and minimum height of each municipality were calculated. For temperature and precipitation, mean, maximum and minimum values were calculated for each municipality (Table 1).

\section{Socioeconomic variables}

For the socioeconomic characterization of the municipalities in the study area, the variables used by the Colombian National Planning Department (DNP) for the study of municipal typology and territorial gaps 25 were used. The DNP grouped variables into six dimensions for the municipal typology and these were incorporated into this analysis: urban functionality, economic dynamics, quality of life, security and institutional. The environmental dimension from the DNP was not included, since other sources of information were used for these variables (IDEAM and IGAC). Data on the corresponding socioeconomic variables was compiled by the DNP using reference information from institutions such as the Colombian National Administrative Department of Statistics (DANE), IGAC, Ministry 
Table 1

Environmental and socioeconomic variables at the municipality level used in the analysis.

\begin{tabular}{|c|c|c|c|}
\hline Variables & Source & Analyzed variables & Description \\
\hline \multicolumn{4}{|l|}{ Environmental } \\
\hline Height above sea level & IGAC & $\begin{array}{l}\text { Mean height above sea level, } \\
\text { altitudinal range, maximum height and } \\
\text { minimum height }\end{array}$ & Level contours every $100 \mathrm{~m}$ \\
\hline Climate & IDEAM & $\%$ of coverage of each type of climate & $\begin{array}{c}\text { According to the humidity provinces of } \\
\text { Holdridge }\end{array}$ \\
\hline Deforestation & IDEAM & $\%$ of deforested area & $\begin{array}{l}\text { From satellite images with 30m } \\
\text { resolution for the period 2005-2014 }\end{array}$ \\
\hline Temperature & IDEAM & $\begin{array}{l}\text { Mean temperature, maximum } \\
\text { temperature and minimum } \\
\text { temperature }\end{array}$ & $\begin{array}{l}\text { Spatially interpolated data from } \\
\text { meteorological stations, with data } \\
\text { from } 1970 \text { to } 2010\end{array}$ \\
\hline Precipitation & IDEAM & $\begin{array}{l}\text { Average rainfall, maximum rainfall and } \\
\text { minimum rainfall }\end{array}$ & $\begin{array}{l}\text { Spatially interpolated data from } \\
\text { meteorological stations, with data } \\
\text { from } 1970 \text { to } 2010\end{array}$ \\
\hline Soil cover & IDEAM & $\begin{array}{c}\text { Multiple uses and covertures of the } \\
\text { soil }\end{array}$ & $\begin{array}{l}\text { Visual interpretation of satellite } \\
\text { images with } 30 \mathrm{~m} \text { resolution }\end{array}$ \\
\hline \multicolumn{4}{|l|}{ Socioeconomic } \\
\hline Population & DNP municipal typology & $\begin{array}{c}\text { Number of inhabitants, \% of } \\
\text { population by area (urban and rest), } \\
\text { population growth, density population } \\
\text { (inhabitants } / \mathrm{km}^{2} \text { to } 2014 \text { ) }\end{array}$ & $\begin{array}{l}\text { Population and housing census with } \\
\text { official projections }\end{array}$ \\
\hline Economic activity & $\begin{array}{l}\text { DNP municipal typology, } \\
\text { MINTIC, SIUST, DDT, and DNP }\end{array}$ & $\begin{array}{l}\text { Municipal aggregate value, municipal } \\
\text { incomes, integration of the internet, } \\
\text { participation of tax revenues in total } \\
\text { income, tax revenue per capita }\end{array}$ & $\begin{array}{l}\text { Developed by the DNP, based on } \\
\text { different sources }\end{array}$ \\
\hline Poverty & DNP municipal typology & Multidimensional poverty index & $\begin{array}{c}\text { Measure of quality of life in } \\
\text { municipalities }\end{array}$ \\
\hline Security & $\begin{array}{l}\text { DNP municipal typology and } \\
\qquad \text { SIMCI }\end{array}$ & $\begin{array}{c}\text { Homicides, kidnappings and thefts } \\
\text { per 100,000 inhabitants, areas planted } \\
\text { with coca }\end{array}$ & Measure of security of the inhabitants \\
\hline Education & DNP & $\begin{array}{l}\text { Education coverage, standardized high } \\
\text { school level exam, illiteracy }\end{array}$ & $\begin{array}{l}\text { Measure of coverage and quality of } \\
\text { education }\end{array}$ \\
\hline Health & DNP and Ministry of Health & $\begin{array}{l}\text { Child mortality, vaccination rate } \\
\text { against diphtheria, Bordetella and } \\
\text { tetanus }\end{array}$ & $\begin{array}{l}\text { Deaths per } 1,000 \text { live births and } \\
\text { vaccination rate }\end{array}$ \\
\hline Quality of housing & DNP municipal typology & $\begin{array}{l}\text { Aqueduct, qualitative housing deficit } \\
\text { and quantitative housing deficit }\end{array}$ & $\begin{array}{l}\text { Infrastructure for water supply, } \\
\text { quantity and quality of housing }\end{array}$ \\
\hline
\end{tabular}

DDT: Direction of Territory Development; DNP: Colombian National Planning Department; IDEAM: Colombian Institute of Hydrology, Meteorology and Environmental Studies; IGAC: Geographic Institute Agustín Codazzi; MINTIC: Ministry of Information and Communication Technologies; SIMCI: Integrated Illicit Crop Monitoring System; SIUST: Unified Information System for the Telecommunications Sector. 
of Information and Communication Technologies (MINTIC), Integrated Illicit Crop Monitoring System (SIMCI), Ministry of Health and Ministry of Education (Table 1). The DNP does not provide socioeconomic data for 20 municipalities in the Amazon region.

\section{Spatial analysis}

Hotspot analysis was calculated by implementing the Getis-Ord Gi method. This method works by analyzing each municipal incidence rate within the context of neighboring incidence rates. A municipal incidence rate with a high value, while interesting, may not be a statistically significant hotspot. For a hotspot to be statistically significant, a municipal incidence rate must present a high value and be surrounded by other municipal incidence rates with high values. The local sum for a municipal incidence rate and its neighbors was proportionally compared to the sum of all incidence rates; when the local sum was much different from the expected local sum, and when such difference was too large to be the result of random chance. The method configured spatial relationships by contiguity and Euclidean distance estimations considering $\mathrm{p}<0.01$. The Getis-Ord Gi method was implemented using the ArcGIS 10.2 software.

\section{Statistical analysis}

Considering that there was a single measurement for the socioeconomic and environmental variables, a decadal incidence coefficient for each municipality was calculated using cases that occurred over the decade as the numerator, and the estimated 2016 population of the municipality as the denominator, assuming that the population level of the municipality was stable over the decade. Following, to identify the municipalities with the highest decadal incidence coefficient, an empirical Bayes smoothing (EBS) was implemented to correct the instability of the variance of the incidence coefficient. EBS decennial incidence coefficient was estimated for all municipalities in Colombia for the 2007-2016 period. The EBS routine in GeoDa 1.8 (https://spatial.uchicago.edu/software) was used 26. The map with cases and decennial incidence coefficient was displayed using natural brakes in ArcGIS 10.2.

The incidence rate ratio (IRR) was calculated using a univariate negative binomial regression. The outcome was the decadal incidence, the independent variable was each socioeconomic and environmental factor, and the exposure was the mean municipality population during the studied period. A correlation matrix was constructed with those variables, considering $\mathrm{p}<0.20$ in the univariate analysis. Variables with a correlation $>0.30$ were probed in a bivariate negative binomial regression, and the associated variable or the variable with the lowest $\mathrm{Z}$ value was included in the saturated model. Following, a multiple negative binomial regression model was estimated using manual backward stepwise elimination. Each eliminated variable was revaluated in a parsimonious multivariate model. Finally, variables with high correlations were probed by interchanging them in this model. Stata 14 software (https://www.stata.com) was used for all statistical analyses.

\section{Results}

\section{Description of human leptospirosis cases}

During the study period, 9,928 human leptospirosis cases were reported to SIVIGILA, with an annual incidence rate ranging from 1.1 (2016) to 5.4 (2011) cases per 100,000 inhabitants for the entire country (median $=1.7$ cases). In total, $661(58.9 \%)$ municipalities presented at least one case of human leptospirosis; of these, the median number of cases reported was 3, ranging from 1 to 704 cases. The municipality with the most cases in the study period was Cali (capital of Valle del Cauca) with 714 cases, followed by Barranquilla (capital of Atlántico) with 436 cases, San José del Guaviare (capital of Guaviare) with 422 cases, Turbo (Antioquia) with 384 cases and Pereira (capital of Risaralda) with 301 cases (Figure 1a).

In general, most (86.6\%) Colombian municipalities had a decadal incidence coefficient of $<35$ decadal cases per 100,000 inhabitants. The municipalities with the highest values were Cairo (Valle del 


\section{Figure 1}

Human leptospirosis cases and decennial incidence coefficient by municipality in Colombia, from 2007 to 2016 (Jenk's natural breaks).

1a) Human leptospirosis cases

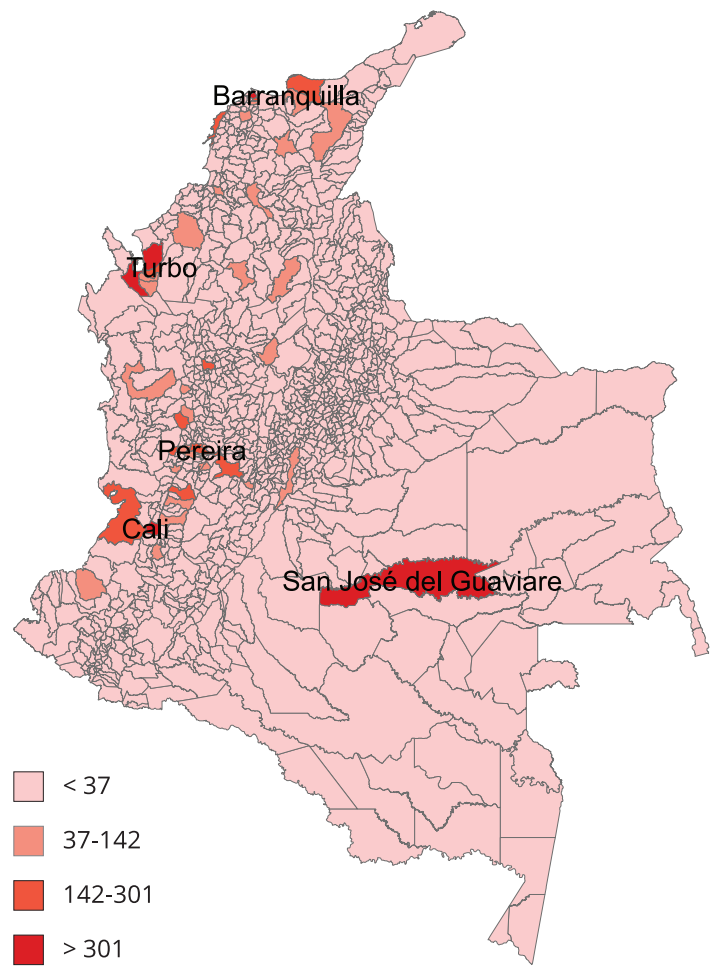

1b) Decennial incidence coefficient

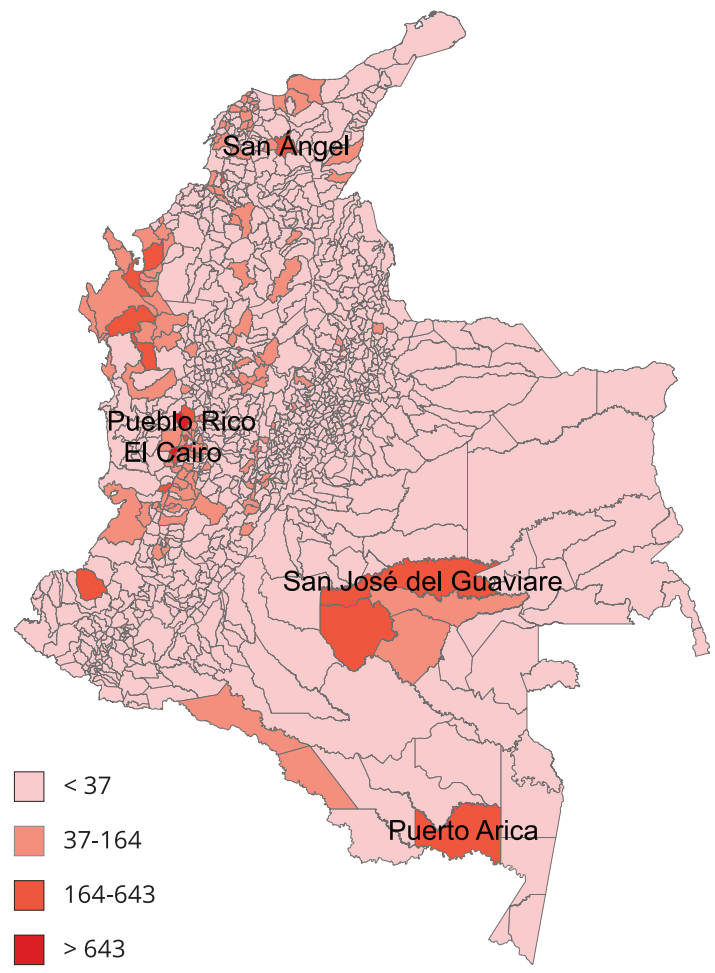

Cauca), Pueblo Rico (Risaralda), San José del Guaviare (capital of Guaviare), Puerto Arica (Amazonas) and San Angel (Magdalena) with 1,950.2, 1,449.7, 643.2, 447.7 and 345.3 decadal cases per 100,000 inhabitants, respectively (Figure 1b).

\section{Environmental characteristics}

The predominant climates in the municipalities are sub-humid and humid. The most frequent coverage was forest, heterogeneous agricultural areas and pastures. These were the most predominant in the Amazon (69.4\%), Pacific (34.6\%) and Caribbean (41.8\%) regions, respectively. The Caribbean region presented the highest percentage of water bodies, with $5.4 \%$ of soil cover presenting this characteristic on average.

The region with the highest mean height was the Andean region, at 1,922 meters above sea level (m.a.s.1.), and the region with the lowest average height was the Caribbean region (388 m.a.s.1.). The Andean region presented the highest deforestation, with a $2.1 \%$ municipal average, and the lowest was observed in the Caribbean (1\%). The highest average temperature was found in the Caribbean region $\left(26.3^{\circ} \mathrm{C}\right)$, and the lowest was in the Andean region $\left(17.5^{\circ} \mathrm{C}\right)$. The highest mean precipitation corresponded to the Amazon region, with 3,265mm. 


\section{Socioeconomic variables}

According to the DNP, territorial gaps are established as benchmarks against expected municipal performance within the national context. The municipalities of the study area were divided according to the typology of DNP gaps: 63.4\% intermediate development, 28.5\% incipient development and $6.2 \%$ robust development. The number of municipalities with the highest development are 54 (8.2\%) in the Andean region, 6 (3\%) in the Caribbean region, 5 (2.8\%) in the Pacific, and 5 (5.1\%) in Orinoquia and Amazon regions. Of the 1,122 municipalities included in the study, 423 (37.7\%) are recognized as small due to populations under 10,000 inhabitants and their generation of free destination municipal income being under 15,000 legal minimum wages.

\section{Incidence hotspots}

Four hotspots of high incidence were identified according the Getis-Ord Gi method. The first hotspot was in the Uraba region and included the municipalities of Carepa, Riosucio and Turbo. The second hotspot included six municipalities in the Choco, Risaralda and Valle departments. The third hotspot was found in the border zone between the departments of Meta, Guania and Guaviare and included eight municipalities. The last cluster included a single locality (El Encanto) in the Amazonia department (Figure 2).

\section{Environmental and socioeconomic determinants of human leptospirosis}

Individually, the decadal incidence of human leptospirosis was associated with 32 of the 49 variables evaluated. Variables not associated with human leptospirosis incidence included temporary crops, coverage of aquatic zones in percentage, anthropic areas, masl rank and maximum masl, as well as deforestation, water bodies, flood areas, areas susceptible to flooding, aqueduct, population density, population growth, municipal income, internet penetration, economic disparity, kidnapping per 100,000 inhabitants and theft per 100,000 inhabitants.

Using a multivariate negative binomial regression model, the environmental variables of percentage of forest coverage, permanent crops and secondary vegetation were associated with an increase in human leptospirosis incidence. Conversely, the percentage of shrubs, arid and pluvial climate, minimum precipitation and minimum masl were related to lower human leptospirosis incidence in the studied municipalities. Regarding socioeconomic variables, homicides were associated with an increase in human leptospirosis incidence; on the other hand, education coverage, performance in standardized high school exams, qualitative housing deficit and the percentage of a non-urban population were related to a lower human leptospirosis incidence in the studied municipalities (Table 2).

\section{Discussion}

The annual incidence of human leptospirosis in Colombia during the last decade ranged from 1.1 to 5.4 cases per 100,000 inhabitants. This result is similar to that calculated by Costa et al. 2 from passive surveillance systems and from epidemiological surveillance in Trinidad and Tobago (1.8 per 100,000 inhabitants) 27 . However, when compared to reports from other surveillance systems, this number is approximately ten times greater than that of Chile between 2003 and 2009 28, but smaller than that of Malaysia between 2012 and 2013 (29.0 per 100,000) 29.

Most previous studies have evaluated regional incidence of human leptospirosis at department scale in Colombia 15,16,30,31,32, and to the best of our knowledge, our study is the first that demonstrates the existence of four hotspots of high human leptospirosis incidence at municipal level. At the regional level, our results are consistent with those observed by other authors, particularly in the Uraba region 33 .

Regarding the environmental determinants of human leptospirosis, different authors $34,35,36$ have linked the occurrence of disease cases to precipitation. We also found this association between minimum rainfall and decadal incidence rate, but the association was positive in the univariate analysis 
Figure 2

Human leptospirosis incidence hotspots.

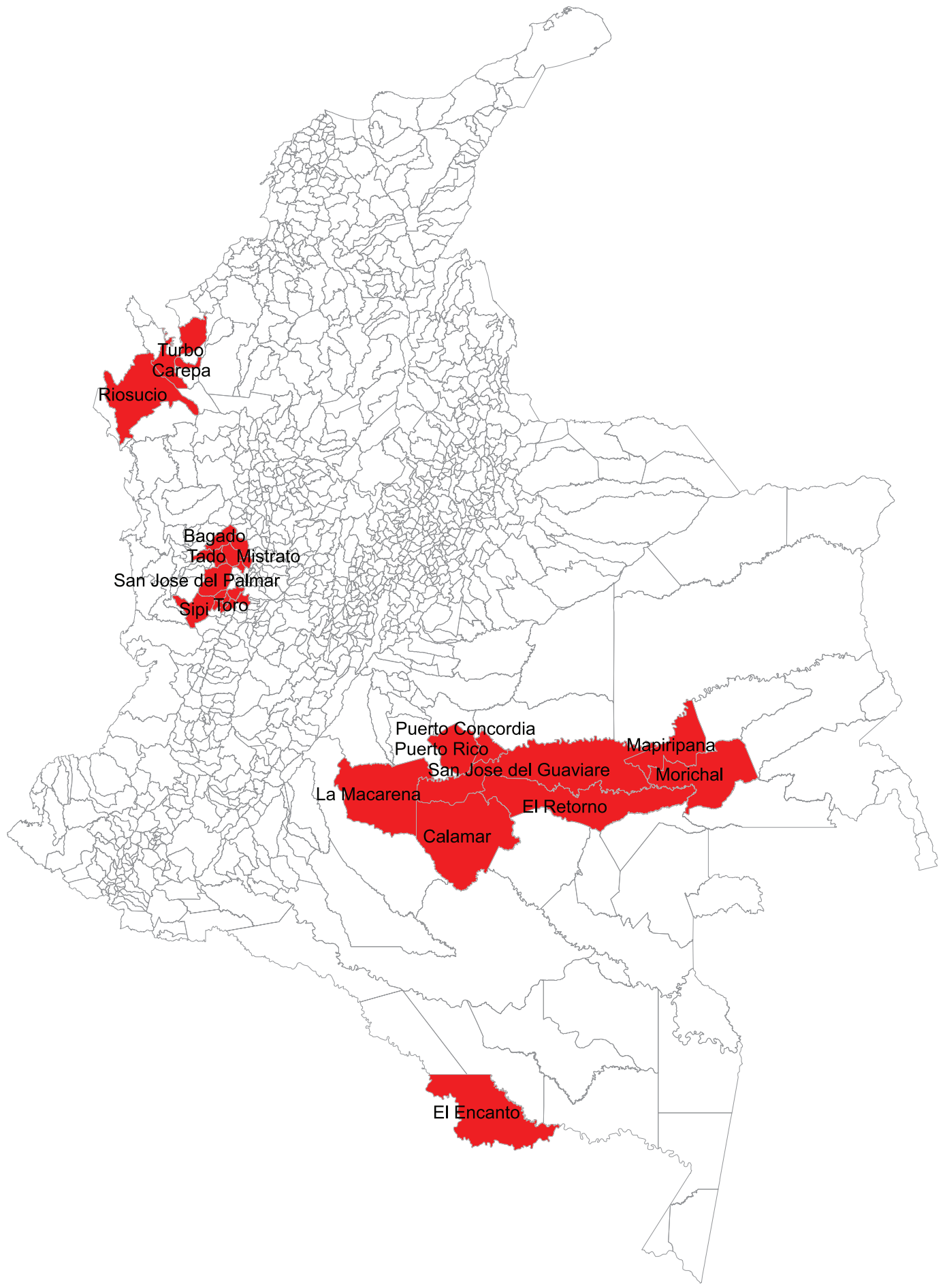


Table 2

Environmental and socioeconomic determinants of the decadal municipality incidence of human leptospirosis.

\begin{tabular}{|c|c|c|c|c|c|}
\hline Variables & IRR & $95 \% \mathrm{Cl}$ & alRR & $95 \% \mathrm{Cl}$ & p-value \\
\hline \multicolumn{6}{|l|}{ Environmental } \\
\hline$\%$ arid climate & 0.952 & $0.918-0.986$ & 0.962 & $0.931-0.994$ & 0.022 \\
\hline$\%$ pluvial climate & 0.986 & $0.974-0.998$ & 0.975 & $0.962-0.987$ & $<0.001$ \\
\hline$\%$ shrubs & 0.967 & $0.960-0.974$ & 0.984 & $0.976-0.992$ & $<0.001$ \\
\hline$\%$ forest & 1.011 & $1.007-1.015$ & 1.013 & $1.008-1.018$ & $<0.001$ \\
\hline$\%$ permanent crops & 1.027 & $1.016-1.038$ & 1.020 & $1.009-1.031$ & $<0.001$ \\
\hline$\%$ secondary vegetation & 1.046 & $1.027-1.065$ & 1.024 & $1.007-1.041$ & 0.006 \\
\hline Minimum m.a.s.l. (100m) & 0.941 & $0.926-0.956$ & 0.951 & $0.934-0.968$ & $<0.001$ \\
\hline Minimum precipitation (100mm) & 1.003 & $1.001-1.004$ & 0.998 & 0.997-0.999 & $<0.001$ \\
\hline \multicolumn{6}{|l|}{ Socioeconomic } \\
\hline Homicides per 100,000 inhabitants & 1.013 & $1.010-1.016$ & 1.005 & $1.003-1.009$ & $<0.001$ \\
\hline Coverage of education & 0.152 & $0.081-0.284$ & 0.337 & $0.154-0.739$ & 0.007 \\
\hline Performance in knowledge exam for high school & 0.879 & $0.848-0.911$ & 0.887 & $0.851-0.925$ & $<0.001$ \\
\hline$\%$ non-urban population & 0.444 & $0.293-0.673$ & 0.376 & $0.242-0.585$ & $<0.001$ \\
\hline Qualitative housing deficit & 0.484 & $0.319-0.736$ & 0.273 & $0.155-0.482$ & $<0.001$ \\
\hline Intercept & NA & NA & 1.531 & $1.363-1.720$ & $<0.001$ \\
\hline
\end{tabular}

95\% Cl: 95\% confidence interval; alRR: adjusted incidence rate ratio; IRR: incidence rate ratio; NA: not available.

and negative in the multivariate analysis. However, both arid and pluvial climates were negatively associated with decadal incidence. In the first case (arid climate) this suggests the importance of soil moisture for the persistence of the infectious agent 37,38. An extremely rainy climate (pluvial) was also associated with a low incidence of human leptospirosis in Colombia. This may be explained by excess of rainfall washing away the bacteria and increasing reservoir movement, as both actions could diminish the probability of Leptospira being present.

Height above sea level and decadal incidence rate showed a negative relationship. This could be associated with the mountainous topography of the country, mainly in the Andean and Pacific regions. A mountainous landscape is not favorable for floods, given the frequency of run-off processes. In comparison, a valley landscape is favorable for the formation of flood-susceptible zones where Leptospira can propagate during wet seasons 39.

Moreover, other authors have shown a significant effect of the climate variation of precipitation on the occurrence of human leptospirosis cases 40,41, which, in Colombia, could be associated with the cold phase of the El Niño Southern Oscillation (ENSO) cycle. However, to formulate a hypothesis that facilitates an understanding of the relationship between ENSO and human leptospirosis, incorporating the magnitude of the local precipitation disturbance is required because within the same region and during the same ENSO phenomenon, there are areas that experience both positive and negative precipitation alterations 42 .

Our results showed a positive relationship between forest coverage and human leptospirosis incidence rate. This is consistent with the observations of other authors in the Uraba region, where areas with larger forest coverage may have a generally increased leptospiral contagion in peridomestic settings 43 . These authors hypothesized that vegetation-induced climate patterns mediate the forest cover-Leptospira association, which could be extended to related vegetation coverage such as permanent crops and secondary vegetation.

Socioeconomic factors determine the socioeconomic status of people in a society and serve as a measure of poverty and vulnerability that influence the population's health 44 . Likewise, socioeconomic status is an important determinant of the probability that individuals and populations will engage in risky behaviors or be exposed to environmental risk factors that directly and indirectly affect their health 44 . 
To the best of our knowledge, our study is the only that shows a positive relationship between homicides and human leptospirosis. Homicide rate is a variable that, in principle, does not seem to be related to the occurrence of human leptospirosis cases. However, homicide rate is a variable related to marginality and lack of opportunities, and we must consider that violence has deep and complex socioeconomic dimensions, thus explaining the significance of this variable in our analysis.

Coverage of education and performance in standardized high school exams are similar variables, both being negatively related to human leptospirosis occurrence. Similar results have been obtained with socioeconomic factors such as illiteracy, which characterizes socially vulnerable populations 34,45,46. Overpopulation in urban areas has been associated with human leptospirosis outbreaks 47 , and in our data, a similar tendency was observed when human leptospirosis incidence decreased in municipalities where the percentage of the population living in non-urban areas was larger. However, in our data, a variable intuitively associated with poor hygiene standards, inadequate sanitation and poverty, such as a quantitative housing deficit, showed a negative association with human leptospirosis incidence and is contrary to observations by other authors 48,49 .

The limitations of this study include underreporting of the disease despite the efforts made by Colombia's government health authorities. No studies on this limitation were found for Colombia, but studies have suggested that underreporting can be about 20 to 49 times the number of reported cases in other Latin American countries, or between $60 \%$ and $90 \%$ of the number of deaths by human leptospirosis 50,51,52. Underreporting continues to be a crucial limiting factor for understanding the epidemiology of human leptospirosis and its associated determinants.

Additionally, our study faced the limitations of aggregating independent variables at municipal level rather than using individual units of analysis at the local transmission scale 53 . However, our results show some degree of consistency with studies performed on an individual scale of analysis, suggesting that within certain spatial limits, the aggregation of information can be a useful tool for the analysis of ecological determinants and yet remain consistent with what is observed at individual scale analyses. In this sense, Piantadosi et al. 54 have suggested that because multidimensional factors seem to contribute to the risk of contracting human leptospirosis, ecological studies be the best possible approach.

In conclusion, human leptospirosis is a disease described as endemic in many areas worldwide and has been recognized as a common infection related to multidimensional poverty. Our study is the first to cover the entire territory of Colombia, including 9,928 cases that occurred over the last decade. Four hotspots of human leptospirosis incidence were identified, including 18 municipalities. Our results highlight the importance of multiple environmental and socioeconomic determinants at the municipal level that are positively associated with the occurrence of human leptospirosis in Colombia. These include forest and similar vegetation coverage (permanent crops and secondary vegetation) and minimum rainfall, as well as socioeconomic determinants related to poverty, overpopulation and violence, as well as education, percentage of non-urban population and homicide rate, respectively. 


\section{Contributors}

J. D. Gutiérrez contributed to the study design and implementation, data analysis and interpretation, writing, and critical revision. R. A. Martínez-Vega contributed to the study implementation, data analysis and interpretation, writing, and critical revision. H. Botello contributed to the data analysis and interpretation, writing, and critical revision. F. J. Ruiz-Herrera contributed to the study design, data analysis and interpretation, and critical revision. L. C. Arenas-López and K. D. Hernandez-Tellez contributed to the study design and implementation, data analysis and interpretation, and critical revision. All authors approved the final version.

\section{Additional informations}

ORCID: Juan David Gutiérrez (0000-0002-6120941X); Ruth Aralí Martínez-Vega (0000-00026477-334X); Hector Botello (0000-0002-77952590); Freddy Jesús Ruiz-Herrera (0000-00034180-7145); Laura Carolina Arenas-López (00000001-8289-675X); Karen Dayana Hernandez-Tellez (0000-0001-5203-1528).

\section{Acknowledgments}

We would like to thank Santander Unviersity and Santander Industrial Unviersity by the time to the study. And too the Colombian National Surveillance System (SIVIGILA) for providing epidemiological data.

\section{References}

1. Ko AI, Goarant C, Picardeau M. Leptospira: the dawn of the molecular genetics era for an emerging zoonotic pathogen. Nat Rev Microbiol 2009; 7:736-47.

2. Costa F, Hagan JE, Calcagno J, Kane M, Torgerson P, Martinez-Silveira MS, et al. Global morbidity and mortality of leptospirosis: a systematic review. PLoS Negl Trop Dis 2015; 9:e0003898

3. Bharti AR, Nally JE, Ricaldi JN, Matthias MA, Diaz MM, Lovett MA, et al. Leptospirosis: a zoonotic disease of global importance. Lancet Infect Dis 2003; 3:757-71.

4. Álvarez L, Calderón A, Rodríguez V, Arrieta G. Seroprevalencia de leptospirosis canina en una comunidad rural del municipio de Ciénaga de Oro, Córdoba (Colombia). Rev UDCA Actual Divulg Cident 2011; 14:75-81.

5. Bermúdez S, Martín-Pulido M, Roy-Andrade B. Seroprevalencia de Leptospira spp. en caninos y humanos de tres barrios de Tunja, Colombia. http://revistas.unicordoba.edu.co/ revistamvz/mvz-153/body/v15n3a06.html (accessed on 22/May/2017).

6. Sánchez-García AE, Pestana JCB, CalderónRangel A, Rodríguez-Rodríguez VC. Leptospirosis: enfermedad endémica en caninos de áreas rurales de Montería (Córdoba). Orinoquia 2010; 14:160-7.

7. Benavides-Romo KLA, Marcillo-Arevalo AR. Seroprevalencia de Leptospira spp. en hembras bovinos de fincas lecheras en el municipio de Pasto, Colombia. Revista Investigación Pecuaria 2016; 4:27-32.

8. Betancur Hurtado C, Orrego Uribe A, González Tous M. Seroepidemiology of leptospirosis in cattle with reproductive disorders from the Municipality of Montería, Colombia. Rev Med Vet (Bogota) 2013; (26):47-55.

9. Arrieta G, Rodríguez V, Calderón A. Seroepidemiología de Leptospira spp., en porcinos de algunos municipios del Sinú medio, departamento de Córdoba - Colombia. Rev MVZ Córdoba 2010; 15:2023-4.

10. Romero MH, Sánchez JA, Astudillo M, González LM, Varela N. Anticuerpos contra Leptospira sp. en primates neotropicales y trabajadores de un zoológico colombiano. Rev Salud Pública 2011; 13:814-23.

11. Romero M, Astudillo M, Sánchez J, González L, Varela N. Títulos de anticuerpos contra Leptospira sp., en primates del zoológico Matecaña, Pereira, Colombia. Rev MVZ Córdoba 2012; 17:3224-30.

12. Cabezas RJ, Tamayo D, Velásquez D, Góngora A, Ocampo A. Asociación serológica de la infección por leptospira en humanos, porcinos y roedores en una granja de Villavicencio-Colombia. Orinoquia 2007; 11:73-80.

13. Giraldo De León G, Orrego Uribe A, Betancurth AM. Los roedores como reservorios de leptospiras en planteles porcinos de la zona central cafetera de Colombia. Arch Med Vet 2002; 34:69-78. 
14. Carreño-Buitrago LA. Prevalencia de leptospirosis en Colombia: revisión sistemática de literatura [Disertación de Maestría]. Bogotá: Facultad de Medicina, Universidad Nacional de Colombia; 2014.

15. Bello S, Rodríguez M, Paredes A, Mendivelso F, Walteros D, Rodríguez F, et al. Comportamiento de la vigilancia epidemiológica de la leptospirosis humana en Colombia, 2007 2011. Biomédica (Bogotá) 2013; 33 Suppl 1:153-60.

16. Pulido-Villamarín A, Carreño-Beltrán G, Mercado-Reyes M, Ramírez-Bulla P. Situación epidemiológica de la leptospirosis humana en Centroamérica, Suramérica y el Caribe. Univ Sci 2014; 19:247-64.

17. Instituto Nacional de Salud. Protocolo de vigilancia en salud pública. Leptospirosis. Bogotá: Instituto Nacional de Salud; 2015.

18. Pappas G, Papadimitriou P, Siozopoulou V, Christou L, Akritidis N. The globalization of leptospirosis: worldwide incidence trends. Int J Infect Dis 2008; 12:351-7.

19. Rodríguez-Bedoya M. Informe del evento leptospirosis, hasta el décimo tercer periodo epidemiológico del año 2012. Bogotá: Instituto Nacional de Salud; 2012.

20. Lau CL, Smythe LD, Craig SB, Weinstein P. Climate change, flooding, urbanisation and leptospirosis: fuelling the fire? Trans R Soc Trop Med Hyg 2010; 104:631-8.

21. World Health Organization; International Leptospirosis Society. Human leptospirosis: guidance for diagnosis, surveillance and control. Geneva: World Health Organization; 2008.

22. Barcellos C, Sabroza PC. The place behind the case: leptospirosis risks and associated environmental conditions in a flood-related outbreak in Rio de Janeiro. Cad Saúde Pública 2001; 17 Suppl:59-67.

23. Desvars A, Jégo S, Chiroleu F, Bourhy P, Cardinale E, Michault A. Seasonality of human leptospirosis in Reunion Island (Indian Ocean) and its association with meteorological data. PLoS One 2011; 6:e20377.

24. Pabón-Caicedo JD, Eslava-Ramírez JA, Gómez-Torres RE. Generalidades de la distribución espacial y temporal de la temperatura del aire y de la precipitación en Colombia. Meteorología Colombiana 2011; 4:47-57.

25. Departamento Nacional de Planeación. Propuesta metodológica para el cierre de brechas terrioriales. Bogotá: Departamento Nacional de Planeación; 2014.

26. Anselin L, Syabri I ,Kho Y. GeoDa: an introduction to spatial data analysis. Geogr Anal 2015; 38:5-22.

27. Chadee DD, Mohan AR, Cumberbatch A, Adesiyun AA. Revised incidence of leptospirosis in Trinidad and Tobago, West Indies. Acta Trop 2010; 113:207.

28. Martínez P, Ortega D, Salinas K. Evolution of leptospirosis according to the National Epidemiological Surveillance System, Chile 20032009. Rev Chil Infectol 2012; 29:648-54.
29. Tan W, Soelar SA, Mohd Suan MA, Hussin N Cheah WK, Verasahib K, et al. Leptospirosis incidence and mortality in Malaysia. Southeast Asian J Trop Med Public Health 2016; 47:43440.

30. Carreño Buitrago LA, Salas Botero D, Beltrán Rios KB. Prevalencia de leptospirosis en Colombia: revisión sistemática de literatura. Rev Salud Pública 2017; 19:204-9.

31. Berger S. Infectious diseases of Colombia. Los Angeles: GIDEON Informatics Inc.; 2018.

32. Dechner A. A retrospective analysis of the leptospirosis research in Colombia. J Infect Dev Ctries 2014; 8:258-64.

33. Agudelo-Flórez P, Restrepo-Jaramillo BN, Arboleda-Naranjo M. Situación de la leptospirosis en el Urabá antioqueño colombiano: estudio seroepidemiológico y factores de riesgo en población general urbana. Cad Saúde Pública 2007; 23:2094-102.

34. Schneider MC, Najera P, Pereira MM, Machado G, dos Anjos CB, Rodrigues RO, et al. Leptospirosis in Rio Grande do Sul, Brazil: an ecosystem approach in the animal-human interface. PLoS Negl Trop Dis 2015; 9:e0004095.

35. Loganathan N, Sudha R, Shivakumar S. Epidemiological profile of human leptospirosis in an Urban South Indian City. National Journal of Research in Community Medicine 2012; 1:127-77.

36. Ferreira MC, Ferreira MFM. Influence of topographic and hydrographic factors on the spatial distribution of leptospirosis disease in São Paulo county, Brazil: an approach using geospatial techniques and GIS analysis. In: XXIII ISPRS Congress. Prague: International Society for Photogrammetry and Remote Sensing; 2016. p. 197-201.

37. Vega-Corredor MC, Opadeyi J. Hydrology and public health: linking human leptospirosis and local hydrological dynamics in Trinidad, West Indies. Earth Perspectives 2014; 1:3.

38. Mwachui MA, Crump L, Hartskeerl R, Zinsstag J, Hattendorf J. Environmental and behavioural determinants of leptospirosis transmission: a systematic review. PLoS Negl Trop Dis 2015; 9:e0003843.

39. Chamizo H. El ambiente natural y la incidencia de la leptospirosis en humanos: Cuba y Costa Rica, resultados de dos estudios ecológicos. Revista Geográfica de América Central 1996; (34):143-57.

40. Herrmann Storck C, Postic D, Lamaury I, Perez JM. Changes in epidemiology of leptospirosis in 2003-2004, a two El Niño Southern Oscillation period, Guadeloupe archipelago, French West Indies. Epidemiol Infect 2008; 136:1407-15.

41. Weinberger D, Baroux N, Grangeon J-P, Ko AI, Goarant C. El Niño Southern Oscillation and leptospirosis outbreaks in New Caledonia. PLoS Negl Trop Dis 2014; 8:e2798. 
42. Montealegre JE. Actualización del componente meteorológico del modelo institucional del IDEAM sobre el efecto climático de los fenómenos El Niño y La Niña en Colombia, como insumo para el Atlas Climatológico. Bogotá: Instituto de Hidrología, Meteorología y Estudios Ambientales; 2014.

43. Padmanabha H, Hidalgo M, Valbuena G, Castaneda E, Galeano A, Puerta H, et al. Geographic variation in risk factors for SFG rickettsial and leptospiral exposure in Colombia. Vector Borne Zoonotic Dis 2008; 9:483-90.

44. Blakely T, Hales S, Woodward A. Poverty: assessing the distribution of health risks by socioeconomic position at national and local levels. Geneva: World Health Organization; 2004

45. Bacallao J, Schneider MC, Najera P, Aldighieri S, Soto A, Marquiño W, et al. Socioeconomic factors and vulnerability to outbreaks of leptospirosis in Nicaragua. Int J Environ Res Public Health 2014; 11:8301-18.

46. Reis RB, Ribeiro GS, Felzemburgh RDM, Santana FS, Mohr S, Melendez AXTO, et al. Impact of environment and social gradient on leptospira infection in urban slums. PLoS Negl Trop Dis 2008; 2:e228.

47. Barcellos C, Sabroza PC. Socio-environmental determinants of the leptospirosis outbreak of 1996 in western Rio de Janeiro: a geographical approach. Int J Environ Health Res 2000; 10:301-13.
48. Ashford DA, Kaiser RM, Spiegel RA, Perkins BA, Weyant RS, Bragg SL, et al. Asymptomatic infection and risk factors for leptospirosis in Nicaragua. Am J Trop Med Hyg 2000; 63:24954.

49. Lau CL, Watson CH, Lowry JH, David MC, Craig SB, Wynwood SJ, et al. Human leptospirosis infection in Fiji: an eco-epidemiological approach to identifying risk factors and environmental drivers for transmission. PLoS Negl Trop Dis 2016; 10:e004405.

50. Brum L, Kupek E. Record linkage and capturerecapture estimates for underreporting of human leptospirosis in a Brazilian health district. Braz J Infect Dis 2005; 9:515-20.

51. Centers for Disease Control and Prevention. Notes from the field: investigation of leptospirosis underreporting - Puerto Rico, 2010. MMWR Morb Mortal Wkly Rep 2012; 61:421.

52. Fontes RM, Cavalcanti LPG, Oliveira ACA, Bezerra LFM, Gomes AMM, Colares JKB, et al. A new possibility for surveillance: do we identify all cases of leptospirosis? Rev Inst Med Trop São Paulo 2015; 57:443-6.

53. Snijders TAB. Multilevel analysis. In: Lovric $\mathrm{M}$, editor. International encyclopedia of statistical science. Berlin: Springer; 2011. p. 879-82.

54. Piantadosi S. Invited commentary: ecologic biases. Am J Epidemiol 1994; 139:761-4. 


\section{Resumen}

La leptospirosis humana es una infección que afecta a la mayoría de países tropicales. Desde 2007, la notificación de esta enfermedad es obligatoria en Colombia, reflejando un aumento de casos observado durante los últimos años. Los objetivos fueron analizar las variables ambientales y socioeconómicas y evaluar su relación con los casos de leptospirosis. Se llevó a cabo un estudio ecológico de casos de leptospirosis humana agregados por municipio, registrados entre 2007 y 2016. La evaluación de la agregación espacial fue desarrollada mediante el Getis-Ord Gi method, y se implementó una regresión negativa binomial para evaluar la relación entre las variables ambientales y socioeconómicas con la leptospirosis humana. Durante el periodo de estudio, se registraron 9.928 casos de leptospirosis humana, y un 58,9\% de los municipios informaron de al menos un caso de leptospirosis. Se identificaron cuatro epicentros de leptospirosis humana, incluyendo 18 municipios. Los resultados del modelo binomial negativo confirmaron la importancia de los efectos de la educación, pobreza y algunas variables climáticas en la tasa de incidencia de leptospirosis humana por decenios. Nuestros resultados confirmaron la importancia de determinantes socioeconómicos tales como: marginalidad social, asociada con la violencia y educación, así como variables ecológicas como: precipitaciones, altura sobre el nivel del mar y superficie forestal en la tasa de incidencia de la leptospirosis humana dentro una escala municipal.

Leptospirosis; Ambiente; Factores

Socioeconómicos; Estudios Ecológicos

\section{Resumo}

A leptospirose humana é uma infecção que majoritariamente afeta países tropicais. Desde 2007, a notificação da doença é compulsória na Colômbia, o que levou a um aumento do número de casos nos últimos anos. Os objetivos foram analisar variáveis ambientais e socioeconômicas e avaliar sua relação com casos de leptospirose humana. Foi feito um estudo ecológico de casos de leptospirose humana notificados entre 2007 e 2016 agregados por município. Uma análise de agregação espacial foi desenvolvida por meio do método Getis-Ord Gi e regressão binomial negativa foi implementada para avaliar a relação entre variáveis ambientais e socioeconômicas e leptospirose humana. Durante o período do estudo, 9.928 casos de leptospirose humana foram notificados e 58,9\% de municípios notificaram ao menos um caso de leptospirose. Quatro hotspots incluindo 18 municípios foram identificados. Os resultados do modelo binomial negativo confirmaram a importância dos efeitos de educação, pobreza e algumas variáveis climáticas na taxa de incidência decenal de leptospirose humana. Nossos resultados confirmam a importância de determinantes socioeconômicos tais como marginalidade social associada a violência e educação, bem como as variáveis ecológicas, tais como precipitação, altitude acima do nível do mar e cobertura florestal sobre a incidencia de leptospirose humana no nivel municipal.

Leptospirose; Meio Ambiente; Fatores

Socioeconômicos; Estudos Ecológicos
Submitted on $10 / \mathrm{Jul} / 2017$

Final version resubmitted on $03 / \mathrm{Jul} / 2018$

Approved on 02/Oct/2018 
Gutiérrez JD, Martínez-Vega RA, Botello H, Ruiz-Herrera FJ, Arenas-López LC, Hernandez-Tellez KD. Environmental and socioeconomic determinants of leptospirosis incidence in Colombia. Cad Saúde Pública 2019; 35(3):e00118417.

doi: 10.1590/0102-311XER118417

Where it reads:

Juan David Gutiérrez 1

Ruth Arali Martínez-Vega 2,3

Hector Botello 4,5

Freddy Jesús Ruiz-Herrera 3,5

Laura Carolina Arenas-López 5

Karen Dayana Hernandez-Tellez 5

1 Facultad de Ingeniería, Universidad de Santander, Bucaramanga, Colombia.

2 Escuela de Medicina, Universidad de Santander, Bucaramanga, Colombia.

3 Ultimate Pipe Control, Bucaramanga, Colombia.

4 Facultad de Ciencias Económicas, Universidad Nacional, Bogotá, Colombia.

5 Escuela de Economía y Administración, Universidad Industrial de Santander, Bucaramanga, Colombia.

It should read:

Juan David Gutiérrez 1

Ruth Arali Martinez-Vega 2

Hector Botello 3,4

Freddy Jesús Ruiz-Herrera 4

Laura Carolina Arenas-López 1

Karen Dayana Hernandez-Tellez 1

1 Facultad de Ingeniería, Universidad de Santander, Bucaramanga, Colombia.

2 Escuela de Medicina, Universidad de Santander, Bucaramanga, Colombia.

3 Universidad Nacional, Bogotá, Colombia.

4 Escuela de Economía y Administración, Universidad Industrial de Santander, Bucaramanga, Colombia. 